\title{
Frequency, causes and cutting-edge treatment of cataract: A review
}

\author{
Latifullah Khan ${ }^{1}$, Rahmat Ali Khan ${ }^{1}$, Wasim Ahmed ${ }^{1}$, Abdur Rauf ${ }^{2,}$, , M. Waqas Khan ${ }^{1}$, \\ Wasiullah Khan ${ }^{1}$, Samran Ahmad Durrani ${ }^{1}$, Saad Qayum ${ }^{1}$ \\ ${ }^{1}$ Department of Biotechnology, Faculty of Biological Sciences University of Science \& Technology, Bannu KPK, Pakistan \\ ${ }^{2}$ Institute of Chemical Sciences, University of Peshawar, Peshawar (25120), KPK, Pakistan
}

\section{Email address:}

rahmatgul_81@yahoo.com (R. A. Khan), mashaljcs@yahoo.com (A. Rauf)

\section{To cite this article:}

Latifullah Khan, Rahmat Ali Khan, Wasim Ahmed, Abdur Rauf, M. Waqas Khan, Wasiullah Khan, Samran Ahmad Durrani, Saad Qayum. Frequency, Causes and Cutting-Edge Treatment of Cataract: A Review. American Journal of Biomedical and Life Sciences. Special Issue: Phytochemical and Pharmacological Study of Medicinal Plants. Vol. 3, No. 2-1, 2015, pp. 25-28. doi: 10.11648/j.ajbls.s.2015030201.14

\begin{abstract}
Cataract is the disease which is prevailing world wide rapidly and health care professionals are making serious efforts to investigate the latest, inexpensive and readily available treatment of the disease. The aim of this review was to investigate the pervasiveness, causes and latest treatment of cataract. However this is a cross sectional study in which we study that Cataract occurs when protein is buildup in the lens and makes it cloudy. So the passing of light clearly through the lens is disturbed thus vision is lost up to some extent. Since on the outside of the lens new lens cells are formed, all the older cells are compacted into the center of the lens resulting in the cataract. Beside of this oxygen free radicals are also involved in cataract because its overproduction can stop the reach of glutathione and other antioxidant into lens where it ceases action of oxidant. Genetically prevalence of cataract also possessed. The gene responsible for cataract is Gamma-S crystalline gene (CRYGS).The only way of cataract removal is surgery although some medication are also present but it is not enough evidence that these lowers the risk for cataract formation.
\end{abstract}

Keywords: Cataract, Lens, Gamma-S crystalline gene, Medication

\section{Introduction}

Cataract accounts for the most dominant reason for blindness around the world, affecting nearly half $(17.7$ million or $47.8 \%$ ) of all blindness victims. ${ }^{1}$ About 10 million cataract surgeries were executed throughout the world In 1997 but in spite of this the ratio of cataract blindness is guessed to be increased by $1-2$ million/year. ${ }^{2}$ To reduce this increasing number of cataract, in many developing countries an efficient struggles are being made for the purpose to increase the output of cataract surgeries ${ }^{3}$. However, it is not patent that all the cataract surgeries will succeeds and there outcome will always be good. Therefore these surgical services needs more attention ${ }^{4}$.In developing countries worldwide About $85 \%$ of the cataract blind people live because the availability of or access to cataract services is poor. Where services are available, But of pathetic quality. ${ }^{5}$, The sixth most populous country of the world is Pakistan with a population of around 154 million people and its population is considered to be double by 2035.It is situated in the Eastern Mediterranean Region of the World Health Organization (WHO), is bordered by, Afghanistan, India, China, and Iran. The country is divided into four provinces: Punjab, Sind, Khyber Pakhtoonkhwa (KPK) and Baluchistan. One of the public health problem in the country is Cataract.1.78\% people in Pakistan were blind (visual acuity in the better eye less than $3 / 60$ with best correction) is judged according to the National Blindness Prevalence Survey conducted during $1987-90,66 \%$ of cases caused by cataract. ${ }^{6}$

Although in past 10 years cataract services have grown considerably in Pakistan, ${ }^{7}$

However this is a cross sectional study and the aim of the review was to investigate the pervasiveness, causes and latest treatment of cataract.

\section{History}

Muslim ophthalmologist Ammar ibn Ali, in his Choice of 
Eye Diseases, wrote about his invention of a syringe and cataract extraction through it. $^{22}$

In Ancient Rome in $29 \mathrm{AD}$ the first references to cataracts and their treatment is found, in the work of the Latin encyclopedist Aulus Cornelius Celsus. ${ }^{23}$ In Roman era Archaeological evidence for eye surgery is also exists. ${ }^{24}$

Other early accounts are found in Sanskrit, Suśruta the Indian physician (about $200 \mathrm{AD}$ ) described the Cataract surgery. ${ }^{25}$

\section{Etymology}

Cataract" is derived from the Ancient Greek word

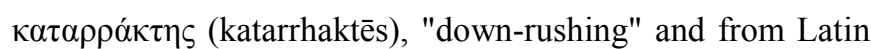
word cataracta, meaning "waterfall" 24 . The name possibly passed through French to form the English meaning "eye disease" (early 15th century), on the notion of "obstruction". 26

\section{Symptoms}

Cataracts may have minute consequence on vision in early stages. Symptoms are different due to different types of cataract in the eye (cortical, nuclear, or posterior subcapsular) The patients experience the following symptoms depending on the type and extent of the cataract.

- Glare and sensitivity to bright lights

- Dual or shadowy image

- Complexity in reading due to compact black-white contrast

- Colors appear faded

- At night difficulty in driving. ${ }^{14}$

\section{Risk Factors}

Aging is the primary risk factor for cataracts, but other factors are also involved which are following.

1. Lower educational standard. ${ }^{11}$ 2. Diabetes. ${ }^{8,9} 3$. Renal failure. ${ }^{9}$ 4. Glaucoma. ${ }^{8,9}$

5. Hypertension. ${ }^{10,8,11}$ 6. Cardiovascular disease. ${ }^{8} 7$. Psychiatric illness. ${ }^{8} 8$. Severe diarrhea. ${ }^{9}$ 9. Myopia when young $^{12}$. 10. Low height, vital capacity and hand grip strength. $^{11}$

Major use of: 12. Tranquillizers. ${ }^{8}$ 13. Diuretics. ${ }^{8} 14$. Topical ophthalmic. ${ }^{8}$ 14. Drugs. ${ }^{8}$ 15. Steroids. ${ }^{9} 16$. Alcohol. ${ }^{8}$ 17. Cigarettes. ${ }^{8}$

High plasma: 18. Fasting glucose (causal glucose). ${ }^{8,11} 19$. Urea $^{8} 20$. Creatinine. ${ }^{8} 21$. Phospholipid. ${ }^{11}$.

Low plasma: 22. Calcium. ${ }^{8}$ 23. Phosphate ${ }^{8}$ 24. Cholesterol. ${ }^{8}$ 25. Albumin. ${ }^{8}$

26. Gender: Men face lower chances than women. ${ }^{13}$

27. Family History: Cataracts tend to run in families. ${ }^{14}$

28. Overexposure to Sunlight: Nuclear cataracts particularly caused by Exposure to UVB (shorter wavelength) radiation from sunlight, especially. The people whose jobs disclose them for a long time to sunlight ${ }^{14}$

29. Environmental Factors: The risk of developing cataracts may increase due to long-term environmental lead exposure .Cataracts also caused by copper and gold assemblage. Prolonged exposure to ionizing radiation (such as X-rays) can increase cataract risk ${ }^{14}$.

30. Oxygen-Free Radicals (Oxidants) and Glutathione: In the eye Glutathione occurs in high levels and helps against free radicals. when the Oxygen-free radicals (also called oxidants) are overproduced in the body by Toxins, smoking, ultraviolet radiation, infections, and many other factors than it can stop the glutathione and other antioxidant to reach to the nucleus in the lens and cause cataract. ${ }^{14}$

31. Genetics: In the development of cataracts the genetic component is strongly involved, most commonly by the way that provide protection ant maintenance to the lens. A particular syndrome can cause a cataract in childhood or in early stages of life occasionally. Examples of chromosome abnormalities associated with cataracts include trisomy 18 (Edward's syndrome),1q21.1 deletion syndrome, Down syndrome, Patau's syndrome, cri-du-chat syndrome, and Turner's syndrome. Examples of single-gene disorder include oculocerebrorenal syndrome or Lowe syndrome, Alport's syndrome and myotonic dystrophy Conradi's syndrome. ${ }^{15}$

\section{Genes Involved in Cataract}

There are 14 genes involved in the pathogenesis of isolated inherited cataract, including seven coding for crystallins (CRYAA [MIM 123580], CRYAB [MIM123590], CRYBA1/A3 [MIM123610], CRYBB1[MIM600929], CRYBB2- [MIM123620], CRYGC[MIM123680], and CRYGD- [MIM123690]), two for gap junctional channel protein (GJA3 [MIM121015] and GJA8 [MIM600897]), two for lens membrane protein (LIM2[MIM154045] and MIP[MIM154050]), one for glucosaminyl (N-acetyl) transferase 2 gene (GCNT2[MIM600429]), one for beaded filament structural protein 2 (BFSP2[MIM603212]), and one for heat shock transcription factor 4 (HSF4[MIM602438]). ${ }^{16,17}$

\section{Types of Cataract}

The Cataracts may be complete or partial, progressive or stationary, soft or hard. The main classification of cataracts to age are cortical, nuclear sclerosis and posterior subcapsular.

\subsection{Cortical Cataract}

The lens cortex (outer layer) becomes opaque in cortical cataracts. In this water content in the outside border of the lens becomes fissure and the appearance is similar to white spokes of a wheel pointing inwards. Glare and light scatter at night are the symptoms of cortical cataract. ${ }^{18}$

\subsection{Nuclear Sclerosis}

Another common type of cataract is Nuclear sclerosis in which central or 'nuclear' part of the lens is affected. With time it becomes harder or 'sclerotic' because of condensation of lens nucleus and deposition of brown pigment within the 
lens. It is also called brunescent cataract. This cataract causes problems in nearsightedness and in distance vision, while reading is less affected. ${ }^{18}$

\subsection{Posterior Subcapsular Cataracts}

In this the lens adjacent to the capsule (or bag) in which the lens sits is becomes cloudy. Because light becomes more focused toward the back of the lens, they can cause unbalanced symptoms for their size. ${ }^{19}$

\subsection{Immature Cataract}

In an immature cataract transparent protein are present upto some extent. ${ }^{20}$

\subsection{Mature Cataract}

Opaque lens proteins are obtained in mature cataract ${ }^{21}$.

\subsection{Hypermature or Morgagnian Cataract}

Liquid lens proteins are formed in a hypermature or Morgagnian cataract. ${ }^{20}$

\subsection{Congenital Cataract}

Congenital cataract, this may be detected in maturity, has a different classification and includes polar, lamellar, and sutural cataracts. $^{20,21}$

\section{How to Avoid Cataract}

The prevention of cataract is not easy but complex process although their occurrence can be delayed by avoiding overexposure to sunlight, stop smoking, avoiding excessive amounts of alcohol, and eating plenty of fresh fruits and vegetables $^{27}$.

\subsection{Treatment}

Medicines and surgery are both involved in the treatment of cataract.

\subsection{Medication}

$\mathrm{N}$-Acetylcarnosine drops are used as a medical treatment for cataracts. These drops reduced oxidation and glycation injure in the lens, particularly reducing crystalline cross linking. ${ }^{28,29}$

Antioxidants, carotenoids, Vitamins such as vitamins $\mathrm{C}$ and $\mathrm{E}$ or fruits and vegetables containing these vitamins are used for the prevention of cataract ${ }^{30}$.

Lutein and zeaxanthin are the carotenids which are used against cataract. $^{30,31}$

\subsection{Surgery}

Various type of surgeries are performed for cataract removal, these are may be, Phacoemulsification, Extracapsular cataract extraction (ECCE) and Intracapsular cataract extraction (ICCE). ${ }^{32}$

\section{Conclusion}

This study provides the reliable estimates of the causes of blindness and visual impairment in the world particularly in Pakistan. About half of the blindness in Pakistan is caused due to cataract along with expanded surgical services, The only treatment of cataract removal is surgery but still one in eight blind adults has visual loss from sequela of cataract surgery. Thatswhy further attention is needed to improve the eye care Services.

\section{References}

[1] Resnikoff S, Pascolini D, Etya'ale D. Global data on visual impairment in the year 2002. Bull World Health Organ 2004; 82: 844-51

[2] World Health Organization. Global initiative for the elimination of avoidable blindness. Geneva: WHO, WHO/PBL/97.61

[3] Limburg H, Vasavada A, Muzumdar G. Rapid assessment of cataract blindness in urban district of Gujarat. Indian J Ophthalmol 1999; 47: 135-41.

[4] Foster A. Cataract—a global perspective: output, outcome and outlay. Eye 1999; 13: 449-53.

[5] Johnson GJ. Improving outcome of cataract surgery in developing countries. Lancet 2000; 355: 158-9.

[6] Memon MS. Prevalence and causes of blindness in Pakistan. J Pak Med Assoc 1992; 42: 196-8.

[7] Ahmad K, Khan MD, Qureshi MB, et al. Prevalence and causes of blindness and low vision in a rural setting in Pakistan. Ophthalmic Epidemiol 2005; 12: 19-23.

[8] Clayton RM, Cuthbert J, Seth J, Phillips CI, Bartholomew RS, Reid JMcK: Epidemiological and other studies in the assessment of factors contributing to cataractogenesis. Ciba Symp 1984, 106: 25-47.

[9] Van Heyningen R and Harding JJ: Do aspirin-like analgesics protect against cataract? A case-control study. Lancet 1986, i: 1111- 13.

[10] Halevi HS and Landau 1: Hospitalized senile cataract in different lewish communities in Israel. Brit Ophthalmol 1962, 46: $285-90$.

[11] Kahn HA, Leibowitz HM, Ganley IP, Kini MM, Colton T, Nickerson RS, Dawber TR: The Framingham Eye Study II. Association of ophthalmic pathology with single variables previously measured in the Framingham Heart Study. Am] EpidemioI1977, 106: 33-41

[12] Van Heyningen R and Harding JJ: Risk factors for cataract: diabetes, myopia and sex. Colloq. INSERM 1986, 147: 381-5.

[13] American Academy of Ophthalmology. Cataract in the Adult Eye, Preferred Practice Pattern. San Francisco: American Academy of Ophthalmology, 2006. Accessed July 1, 2008.

[14] University of Maryland Medical center $\mathrm{http} / / / \mathrm{umm} . \mathrm{edu} /$ health/medical/reports/articles/cataracts

[15] http://en.wikipedia.org/wiki/Cataract\#Genetics 
[16] Hammond CJ, Snieder H, Spector TD, Gilbert CE. Genetic and environmental factors in age-related nuclear cataracts in monozygotic and dizygotic twins. N Engl J Med 2000; 342: 1786-90.

[17] Hammond CJ, Duncan DD, Snieder H, de Lange M, West SK, Spector TD, Gilbert CE. The heritability of age-related cortical cataract: the Twin Eye Study. Invest Ophthalmol Vis Sci 2001; 42: 601-5.

[18] Bollinger KE, Langston RH (2008). "What can patients expect from cataract surgery?". Cleveland Clinic journal of

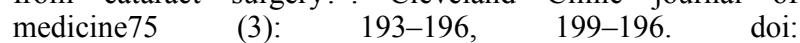
10.3949/ccjm.75.3.193.PMID 18383928

[19] "Posterior Subcapsular Cataract". Digital Reference of Ophthalmology. Edward S. Harkness Eye Institute, Department of Ophthalmology of Columbia University. 2003. Retrieved 2 April 2013

[20] Spencer RW, Andelman SY (1965). "Steroid cataracts. Posterior subcapsular cataract formation in rheumatoid arthritis patients on long term steroid therapy". Arch Ophthalmol 74: 38-41.

[21] Greiner JV, Chylack LT (1979). "Posterior subcapsular cataracts: histopathologic study of steroid-associated cataracts". Arch Ophthalmol 97 (1): 135-44.

[22] Finger, Stanley (1994). Origins of Neuroscience: A History of Explorations Into Brain Function. Oxford University Press. p. 70.ISBN 0-19-514694-8

[23] Aulus Cornelius Celsus, G. F. Collier (transl.) (1831). De Medicinae. OL 5225311W.
[24] Elliott, Jane (February 9, 2008). "The Romans carried out cataract ops". BBC News.

[25] Suśruta, P. V. Sharma (trans.) (2000). Suśruta-Saṃhitā 1. Varanasi: Caukhambha Visvabharati. p. iv. OL 160267M.

[26] Online Etymology Dictionary, etymonline.com

[27] Fernandez MM, Afshari NA. Nutrition and the prevention of cataracts. Curr Opin Ophthalmol. 2008 Jan; 19(1):66-70.

[28] Williams DL, Munday P (2006). "The effect of a topical antioxidant formulation including $\mathrm{N}$-acetyl carnosine on canine cataract: a preliminary study". Vet Ophthalmol 9 (5): $311-6$.

[29] Guo Y, Yan H (2006). "Preventive effect of carnosine on cataract development". Yan Ke Xue Bao 22 (2): 85-8.

[30] Fernandez MM, Afshari NA. Nutrition and the prevention of cataracts. Curr Opin Ophthalmol. 2008 Jan; 19(1): 66-70.

[31] Spencer RW, Andelman SY (1965). "Steroid cataracts. Posterior subcapsular cataract formation in rheumatoid arthritis patients on long term steroid therapy". Arch Ophthalmol 74: 38-41.

[32] Dr. Kushal Banerjee (2006). "A review and clinical evaluation of per-operative and post-operative complications in case of manual small incision cataract surgery and extracapsular cataract extraction with posterior chamber intra-ocular lens implantation". Retrieved1 June 2014. 